\title{
Pharmaceutical Price Convergence In The EU: Preliminary Results From The Panel Data Unit Root Test
}

Aysegul Timur, Ph.D., Hodges University, USA

\begin{abstract}
This paper explores the case of market integration and price convergence in the European Union, specifically in the pharmaceutical industry. The EU has been experiencing market integration since 1992, through the removal of trade barriers, the establishment of a single market, and the reduction of exchange rate volatility. In addition, there have been several structural reforms in product markets designed to increase competition, monitor cross-country price differences and increase transparency. One anticipated effect of market integration is price convergence, because of the reduced potential for price discrimination across the $E U$. This paper is aimed to analyze market integration and price convergence in the European pharmaceutical market, which is the fifth largest industry in the EU. Since 1985, many EU directives have been adopted to achieve a single EU-wide pharmaceutical market, with the aim of enhancing the quality of life for European citizens and the European pharmaceutical industry's competitiveness and research and development capability. Using annual 1994-2003 IMS Health panel data from five EU countries on prices of drugs used to treat cardiovascular disease and controlling drug and market characteristics; this paper examines how the integration process has affected cross-country drug price dispersion in the EU through the preliminary results from the panel data unit root test. Finally, the results show some evidence of price convergence in the pharmaceutical market, with long term price differences arising from country fixed effects.
\end{abstract}

Keywords: Pharmaceutical; Single Market; Panel Data; IMS Health Data; Panel Unit Root Test

\section{INTRODUCTION AND LITERATURE REVIEW}

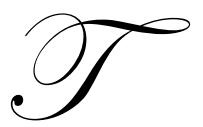

his paper explores the case of market integration and price convergence in the European Union, specifically in the pharmaceutical industry. The European Commission recognizes the importance of price competition and price convergence through a single market program: "The removal of barriers and the freedom of supply which businesses will enjoy as a result of the single market program should lead, through increased competitive pressure, to some downward convergence of prices of benefit to the customer. From the point of view of producers, the competitive pressure will be exerted first and foremost on price-cost margins, particularly in those sectors in which they held a certain monopoly power or position. Producers will also be induced - urged on by pressure on their margins - to become more efficient and thus cut their production and distribution costs. The increased pressure which will be brought to bear in this way on costs and price-cost margins will be a powerful means of causing prices to converge on levels more consistent with economic and technical efficiency" (DRI 1996). Furthermore, the EU Treaty also requires the Commission and the European Central Bank to report on convergence at the macroeconomic level because convergence will ensure that a single EMU interest rate is appropriate for all participants. Moreover, when the EMU is hit by a macroeconomic shock, a high degree of convergence limits asymmetric economic developments at the country level, which can no longer be addressed by adjusting the exchange rate (European Commission 2004). Finally, price convergence indicates the evolution of product market integration. 
DRI (1996) showed a trend towards price convergence in the EU-12 during 1980-1993 using price indexes for detailed product and service categories collected by Eurostat. This trend was more pronounced for consumer and equipment goods than for energy, services, and construction. The convergence in consumer products and services has accelerated since the single market program. Convergence has been comparatively greater for the three 1989 entrants (Greece, Portugal and Spain) than the EU-9, which may reflect a catch-up effect of integration. The product categories with the greatest convergence were in highly traded (more open) industries. Four products and services related to health care had the highest price disparities in 1993. The study concluded that 78 product/services categories, representing $60 \%$ of EU private consumption expenditures, had significant price convergence, compared to only eight cases of price divergence (DRI 1996).

Using Eurostat panel data for 1975-1995 on monthly consumer price indexes for 12 EU countries, Sosvilla-Rivero and Gil-Pareja (2004) examined how European market integration has affected cross-country price dispersion in the EU. They used the Levin and Lin (1992) convergence equation to test for unit roots with panel data, with Germany as the benchmark country based on its central role in the EMS. The estimated speed of convergence $(\beta)$ for the general CPI was -0.006 , which implies a half life of a shock of 115 months. The highest estimated $\beta$ was for fruits $(-0.073)$ with a half life of 9 months, and the lowest estimated $\beta$ was for recreation (0.001) with a half-life of 693 months. The study concluded that there was empirical evidence of price convergence, especially for traded goods. The study failed to obtain such evidence in the cases of non-tradable goods or goods that are subject to special taxes or regulations.

A similar study by Gil-Pareja and Sosvilla-Rivero (2004) examined the degree and recent evolution of export-price dispersion between 1988 and 2001 among seven EU countries (Belgium-Luxembourg, France, Germany, Italy, the Netherlands, Spain and the UK) for a number of eight-digit products using the Eurostat data. The data set was based on the annual free on board (f.o.b.) value and quantity of exports to selected OECD countries. It is expected that relatively fixed exchange rates established by EMS would result in price convergence by imposing price discipline among its members. As a measure of export-price dispersion, they used the coefficient of price variation, i.e. the ratio of the standard deviation to the mean, which is invariant to changes of scale. To assess price convergence, the time series of variation for each source country-product pair were regressed on a constant and a linear time trend. The results of the study showed that export-price dispersion was usually lower in the sample than across OECD countries. There was little evidence of convergence, but this was also stronger across the EU countries. The conclusion was that although monetary stability may aid price convergence, it does not necessarily lead to complete convergence.

Two other studies, Rogers (2001) and Rogers et al. (2001), found direct evidence of price convergence in Europe, using European price indices from actual prices of 168 goods and services, in 26 cities, in 18 countries, between 1990 and 1999. Prices became less dispersed in the euro area and convergence was evident for traded goods, more in the first half of the 1990s than the second half. By some measures, traded goods price dispersion across the euro area was close to that across US cities.

European Commission (2004) also concluded that there is a continuing convergence of prices of recent entrants towards the considerably higher levels in the EU-15, again due to the catching-up process and price deregulation. As a result, price convergence in the new member states has been faster than in the EU-15.

Camarero et al. (2000) examined price and inflation convergence between three European countries (Italy, Spain and the UK). The results rejected long-run convergence in all cases but found that prices catch up with the European average.

There have been several studies of price convergence in specific EU product markets, particularly the car market (Gaulier and Haller 2000;Goldberg and Verboven 2001; 2004;Verboven 1996). Goldberg and Verboven (2005) investigated the relationship between integration and price convergence using panel data on car prices between 1970 and 2000. Approximately 150 vehicles per year and five markets [Belgium (the benchmark country), France, Germany, Italy and the UK] were included. They found strong evidence of both the absolute and relative versions of the Law of One Price. Hedonic regressions were estimated to control for possible variations in characteristics of models across countries, and these quality-adjusted prices were used to form the dependent variable for the Levin and Lin (1992) convergence equations. The relative version of the Law of One Price implied 
half lives of shocks between 1.3 and 1.6 years.

Kerem et al. (2005) estimated the convergence of health care expenditures in the EU using $\beta-, \sigma^{-}, \gamma-$ convergence for the 1992-2001 period. The study demonstrated that even though economic integration has facilitated economic growth, the EU's enlargement process has not brought about harmonization of health care expenditures in the EU-8 new member states (Czech Republic, Estonia, Hungary, Latvia, Lithuania, Poland, Slovakia, and Slovenia). It would take approximately three years for health care expenditures as a share of GDP in the EU-8 countries to move halfway to the EU-15 average.

Lastly, Ratfai (2006) examined price convergence among geographically close locations that share the same currency, using a sample of highly disaggregated product level prices of very narrowly defined homogeneous items in Hungary. Employing a series of panel data unit root tests using the Levin et al. (2002) procedure, the results showed price differentials fading away quickly, with an estimated half-life of between 2.2 and 12.0 months and a median half-life of 4.0 months.

Price convergence in pharmaceutical markets has not been subject to empirical investigation, thus this paper attempts to do so. However, the pharmaceutical industry has been placed high among the most sensitive sectors of the single market program (Allen, et al. 1998).

\section{METHODOLOGY}

It is expected that market integration of sourcing, retailing and distribution contributes to price convergence among EU countries (Coopers 1996). However, because the relationship between European integration and price convergence depends on many different structural, behavioral, and policy factors that differ across markets, price convergence patterns are expected to vary by industry. The objective of this paper is to preliminary test the hypothesis of price convergence in the EU pharmaceutical industry. The methods of controlling for the quality and market characteristics and the model specifications are adopted from Goldberg and Verboven (2005) and Danzon and Chao (2000).

\section{Data}

The data for this paper represent selected cardiovascular pharmaceuticals. They come from IMS Health, which collects and reports sales and price data at the level within the pharmaceutical market supply and distribution chain that provides the most accurate information for a country (IMS 2005a). Of the 29 IMS Health three-digit CVD categories, this analysis samples the eight studied by Dickson and Jacobzone (2003). These categories cover a wide range of both newer and older innovations that form the core of pharmacotherapy for CVD.

The five countries in the sample are Germany, the UK, Italy, Spain, and France. These countries have the largest pharmaceutical production and sales in the EU-15 (OECD 2003) and represent the five largest pharmaceutical markets in the world after the US and Japan (Pammolli, et al. 2004). Restricted as described above, the IMS Health data include 658 molecules (119 for France, 177 for Germany, 135 for Italy, 119 for Spain and 108 for the UK) for the 1994-2003 period. Different data sets are constructed for different parts of the analysis. Depending on the benchmark country, an average of 50\% of retail sales do not match bilaterally and thus are not included.

Quasi-hedonic price regressions are based on a balanced panel of all 379 molecules over 10 years and five countries, yielding sample sizes of 3,790. To form the dependent variable in the price convergence regressions, two distinct bilateral matched samples are constructed, with 3,210 and 2,940 observations depending on whether Germany or Spain, respectively, serves as the base country. Another sample is constructed to form the dependent variable measured in deviations from the cross country average. This sample includes all 379 molecules and has 3,790 observations. 


\section{Definition of Price in the IMS Data}

Prior to Danzon (1999), cross country studies compared the price for a single drug pack in the base country, but this pack may not be typical or even available in other countries (Berndt 2000). Danzon recognized that samples using only comparison packs with the same ingredient, manufacturer, brand name, dosage form, pack size and strength in each country will exclude generic and OTC products. These are likely close substitutes for originator and prescription drugs, respectively, so their omission will potentially result in unrepresentative samples (Hellerstein 1998), a problem that might be exacerbated by not including all forms and strengths (Ellison, et al. 1997;Scherer 1993;Scherer 2000). Danzon therefore defined the drug by active ingredient, i.e. molecule (MOL), and ATC without regard to manufacturer and brand name. All forms of a given molecule, including generics and licensed products, are combined to form a weighted average price per MOL/ATC. Differences between products with identical MOL and ATC are ignored, but this is presumed to be much less problematic than failing to sample substitutes and all forms and strengths.

The IMS Health measure that meets the criteria of being available for all dosage forms and strengths is the IMS Standard Unit (SU), which defines a single dose as one tablet or capsule, five milliliters of a liquid (i.e. one teaspoon), or one ampoule or vial of an injectable product (IMS 2002; 2005b). Aggregation of all dosage forms, strengths, and packs minimizes sample selection bias. Danzon and Kim (1998) found that this strategy permits over 90\% of sales to be included for the US, the UK and Canada, and encompasses over two-thirds of sales for most other countries. Therefore, price (Leusuprice) is the average price per standard unit for each ATC/molecule, defined as the volume-weighted average retail price over all forms and packs. Local currency prices are converted to euros by IMS Health using constant exchange rates, which minimize effects of exchange rate fluctuations.

\section{Quasi-Hedonic Price Regressions}

The first step is to estimate the quasi-hedonic regressions in order to generate price measures that control for variation in characteristics of the drug. The semi-log model is adapted,

$$
\ln P_{k, j, t}=\beta X_{k, j, t}+\gamma_{t}+\delta_{j}+\theta_{j, t}+c_{k}+u_{k, j, t},
$$

where $\ln P_{k, j, t}$ is the $\log$ price per SU for molecule $\mathrm{k}$ in country $\mathrm{j}$ and year $\mathrm{t}, X$ is a vector of quality and market characteristics for that molecule, country and year $\mathrm{t}, \gamma_{\mathrm{t}}$ is year indicators, $\delta_{\mathrm{j}}$ is country indicators, $\theta_{j, t}$ is an interaction between indicators for country $\mathrm{j}$ and year $\mathrm{t}, c_{k}$ is an indicator for molecule $\mathrm{k}$, and $u_{k, j, t}$ is the remaining error, which represents cross country price differences that cannot be explained by observable drug characteristics, specific molecules available and average year-specific price differences. The second step uses the residuals from these regressions as the prices in the price convergence regressions.

\section{Panel Data Unit Root Test}

As it is explained above, quasi-hedonic price regressions (without time, country and time-country interaction indicators) are used to form the dependent variable in the price convergence equations. In particular, the residuals capture price variation that cannot be attributed to observable characteristics, trends in price differences specific to country pairs, or specific molecules. These thus form the relevant prices in the price convergence regressions. Goldberg and Verboven (2005) used a similar method to test price convergence in the EU car market.

A common approach to examining price convergence is to apply a unit root test to determine whether price differential series are stationary, i.e. have mean and variance that do not vary systematically over time and are thus stable. The rejection of the unit root hypothesis implies that relative prices have stationary time series and will thus converge in the long run. Failure to reject the unit root hypothesis implies that relative prices follow a random path, so that any deviation from a single price becomes permanent (Fan and Wei 2006). Moreover, presence of a unit root implies that a shock today has a long lasting impact, determining whether a process has a unit root is of interest in its own right. Unit root tests for a single time series, such as the often used Augmented-Dickey Fuller test, have low power in the sense that they too often reject stationarity. Levin et al. (2002) showed that use of a unit root test for 
panel data can significantly increase test power (Maddala 1999;Maddala and Wu 1999). Their model assumes that each panel unit shares the same AR(1) coefficient, but allows for individual and time effects and a time trend. This test may be viewed as a pooled Dickey-Fuller test or an Augmented Dickey-Fuller test when lags are included, with the null hypothesis of nonstationary (Bornhorst and Baum 2001).

The following convergence equations are based on the panel data unit root test developed by Levin and Lin (1992; Levin and Lin 1993) and Levin et al. (2002):

Model 1: $\Delta p_{k, j, t}=\beta p_{k, j, t-1}+\sum_{l=1}^{L} \gamma_{l} \Delta p_{k, j, t-l}+\varepsilon_{k, j, t}$

Model 2: $\Delta p_{k, j, t}=\alpha_{k, j}+\beta p_{k, j, t-1}+\sum_{l=1}^{L} \gamma_{l} \Delta p_{k, j, t-l}+\varepsilon_{k, j, t}$

Model 3: $\Delta p_{k, j, t}=\alpha_{k, j}+\beta p_{k, j, t-1}+\delta t+\sum_{l=1}^{L} \gamma_{l} \Delta p_{k, j, t-l}+\varepsilon_{k, j, t}$

In model 1 , the null hypothesis $\mathrm{H}_{0}: \beta=0$ is tested against the alternative $\mathrm{H}_{1}: \beta<0$.

In model 2, individual molecule/country fixed effects are added, and $\mathrm{H}_{0}: \beta=0$ and $\alpha_{\mathrm{j}, \mathrm{k}}=0$ is tested against $\mathrm{H}_{1}: \beta<0$ and $\alpha_{\mathrm{j}, \mathrm{k}} \neq 0$.

In model 3, a time trend is added, and $\mathrm{H}_{0}: \beta=0$ and $\delta=0$ is tested against $\mathrm{H}_{1}: \beta<0$ and $\delta \neq 0$.

These three models serve different purposes. The first is used to test the absolute version of the Law of One Price, while the second model is used to test the relative version of the Law of One Price. Model 3 is not preferred in the literature but it is estimated for both adjusted and unadjusted price convergence estimations to compare the results. For series that have clear time trends, the process must be modified to test for unit roots. A trend stationary process can be mistaken for unit root process if we do not control for a time trend.

The convergence equation dependent variable represents the first difference in the log-price of molecule $\mathrm{k}$ in country $\mathrm{j}$. This first difference is specified relative to a base country in one specification, and relative to the cross country average in another. In other words, if q represents log price, the two dependent variable specifications are

1) $\Delta p_{k, j, t}=p_{k, j, t}-p_{k, j, t-1}$, where $p_{k, j, t}=q_{k, j, t}-q_{k, \text { BaseCounty }, t}$ and $\mathrm{p}_{\mathrm{k}, \mathrm{BaseCountry}, \mathrm{t}}=1$;

2) $\Delta p_{k, j, t}=p_{k, j, t}-p_{k, j, t-1}$ with $p_{k, j, t}=q_{k, j, t}-q_{\text {Crosscountyaverage } j, t}$.

The test for unit roots relates the first difference to the log price of the previous period; if the coefficient of the previous period's price is negative, price differentials across countries become smaller over time $(\beta<0)$ and the hypothesis of a unit root is rejected. Therefore, $\beta$ denotes the speed of convergence. Under the null hypothesis of no convergence, $\beta=0$ and a shock to $\mathrm{p}_{\mathrm{k}, \mathrm{j}, \mathrm{t}}$ is permanent (i.e. has a unit root). If $\beta \geq 0$, the price differential is nonstationary, implying persistent price divergence. If $\beta<0$, prices converge. The coefficient estimate is tested according to the critical values reported in Levin and Lin $(1992,1993)$ and t-star statistics (adjusted t statistics, tabulated in Levin et al. 2002) are also reported. After transformation by factors provided by Levin and Lin (1992, 1993), the t-star statistic is distributed standard normal under the null hypothesis of nonstationarity. The half-life of a shock to the price differential is $\frac{-\ln (2)}{\ln (1+\beta)}$.

Model 2, used to test the relative version of the Law of One Price, is the primary focus of this study. The $\alpha_{\mathrm{k}, \mathrm{j}}$ capture price differences that are specific to country pairs and molecules. Large values would indicate market segmentation. Even in integrated markets, some permanent cross-country price dispersion might remain, reflecting 
local factors that cannot be arbitraged away. If this dispersion fully explains any price differentials, the relative version of the Law of One Price holds. If instead prices of identical products are equal across countries, the absolute version of the law of one price holds (Goldberg and Verboven 2004). Dividing these fixed effects by $-\beta$ yields the long-term systematic price differentials across countries. For brevity, the average $\alpha_{\mathrm{j}, \mathrm{k}}$ across molecules by country is reported.

The lags (L) $\Delta p_{k, j, t-l}$ are used to account for possible serial correlation in the error term. Because of the limited number of years available in the data set, the estimations include lags of zero, one or two years, consistent with previous studies. In addition to these, Campbell and Perron's top-down approach (Pammolli, et al. 2004) is also used to find optimum amount of lag order when the equations are estimated. In this approach, the lag order is set to a maximum of two lags for each molecule/country estimation. If the absolute value of the t-statistic of $\gamma_{2}$ is less than 1.96, the lag order is set to one lag and the equation is re-estimated. If this t-statistic is less than 1.96, no lags are included.

\section{FINDINGS/ RESULTS}

The results from the quasi-hedonic regressions suggest that bilateral drug price differences are decreasing. Although price differences still exist because of diverging health system regulations, market integration and continued coordination efforts of the European Commission, they indicate that there is a movement towards a single pharmaceutical market in the EU (Timur, et al. 2010). However, our focus in this preliminary study is not the price differences, instead empirical evidence on price convergence.

The regression coefficients provide estimates of the speed of the convergence to the law of one price, which indicates how quickly deviations from long term price differentials are eliminated. Table 1 reports estimation results with Spain and Germany as base countries. The Hausman test rejects the null hypothesis of fixed and random effects equivalence, thus fixed effects models are used to form the dependent variables for the convergence equations. The results are robust for zero, one and two lags, in addition to the Campbell and Perron (1992) top down approach, with the latter reported in the tables.

Table 1

Results for Price Convergence Estimations for All Molecules (Adjusted by FE)

\begin{tabular}{|c|c|c|c|c|}
\hline 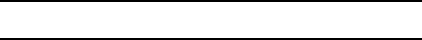 & \multicolumn{2}{|c|}{ Model 1} & \multicolumn{2}{|c|}{ Model 2} \\
\hline Dependent Variable: $\Delta \mathrm{P}_{\mathrm{i}, \mathrm{k}, \mathrm{t}}$ & Base: SPN & Base: GR & Base: SPN & Base: GR \\
\hline$\beta^{1}$ & 0.01 & -0.02 & -0.18 & -0.17 \\
\hline Half-life of Shock (in years) & - & 34.3 & 3.5 & 4.4 \\
\hline $\mathrm{FR}^{2}$ & - & - & 0.02 & 0.01 \\
\hline $\mathrm{GR}^{\mathrm{b}}$ & - & - & 0.08 & - \\
\hline $\mathrm{UK}^{\mathrm{b}}$ & - & - & 0.15 & 0.00 \\
\hline $\mathrm{SPN}^{\mathrm{b}}$ & - & - & - & -0.08 \\
\hline $\mathrm{ITY}^{\mathrm{b}}$ & - & - & 0.06 & -0.08 \\
\hline Lags of $\Delta \mathrm{P}_{\mathrm{i}, \mathrm{k}, \mathrm{t}}$ & $\operatorname{Yes}(1)^{3}$ & $\operatorname{Yes}(1)^{\mathrm{c}}$ & $\mathrm{Yes}^{4}$ & Yes $^{\mathrm{d}}$ \\
\hline t-star & 8.89 & -19.25 & -8.39 & -8.34 \\
\hline $\mathrm{P}>\mathrm{t}$ & 1.000 & 0.000 & 0.000 & 0.000 \\
\hline Molecule/Country Fixed Effects & No & No & Yes & Yes \\
\hline Time Trend & No & No & No & No \\
\hline $\mathrm{N}$ & 2,940 & 3,210 & 2,940 & 3,210 \\
\hline
\end{tabular}

\footnotetext{
${ }^{1} \beta$ coefficients are estimated by the Levin et al. (2002) panel unit root test module in Stata ${ }^{\mathrm{TM}} 9.2$ (levinlin).

2 Country fixed effects are estimated for each molecule/country by the Augmented Dickey Fuller regressions in Stata ${ }^{\mathrm{TM}} 9.2$ (dfuller) and then averaged for each country.

${ }^{3}$ The average number of lags for each molecule/country is 1 .

${ }^{4}$ The number of lags is determined by using the Campbell and Perron top-down approach.
} 
Model 1 does not include molecule/country fixed effects and thus tests for convergence to the absolute version of the law of one price. The null hypothesis is that the price differences converge toward zero in the long run, i.e. $\beta<0$. The $\beta$ coefficient is negative in the specification where Germany is the base country, with an implied half-life of a shock, i.e. $-\ln (2) / \ln (1+\beta)$, of 34.3 years. This half-life of 34.3 years is longer than the typical life cycle of a drug and provides little, if any evidence of convergence. When Spain is the base country, the $\beta$ coefficient is positive, indicating that there is no evidence of the absolute version of law of one price holding. The positive sign of the coefficient actually implies persistent price divergence. The results are mostly consistent with the international trade literature.

Model 2 tests the relative version of the law of one price and finds estimated $\beta$ ranges between -0.17 and 0.18. Based on the adjusted $\mathrm{t}$ statistics ( $\mathrm{t}$-star) values, the unit root hypothesis is rejected, signifying significant evidence of price convergence. The implied half-lives of shocks, according to these $\beta$ estimates, are between 3.5 and 4.4 years. These half-lives are longer than found in the recent international trade literature (Goldberg and Verboven 2005).

The $\alpha_{\mathrm{i}, \mathrm{k}}$ in model 2 captures molecule country fixed effects that account for non-time dependent, molecule specific price differences across countries. Such effects could include transportation costs, unobserved quality differences that vary by destination, or markup differences. The presence of molecule/country fixed effects in the estimations implies testing the relative version of law of one price. The average molecule/country specific fixed effects are displayed in table 1 . These large values of molecule/country fixed effects indicate market segmentation even if the relative version of law of one price holds in the data, consistent with other studies in the literature. By dividing the fixed effects by $-\beta$, long-term systematic price differences relative to Spain of $83 \%$ for the UK, $33 \%$ for Italy, $11 \%$ for France, and $44 \%$ for Germany are obtained. When Germany is the base country, long term price differentials are $6 \%$ for France, $0 \%$ for the UK, and $-47 \%$ for Spain and Italy.

Similar convergence coefficients are obtained for both the absolute and the relative version of law of one price, using prices from random effect models (table 2).

Table 2

Results for Price Convergence Estimations for All Molecules (Adjusted by RE)

\begin{tabular}{|c|c|c|c|c|}
\hline & \multicolumn{2}{|c|}{ Model 1} & \multicolumn{2}{|c|}{ Model 2} \\
\hline Dependent Variable: $\Delta \mathrm{P}_{\mathrm{i}, \mathrm{k}, \mathrm{t}}$ & Base: SPN & Base: GR & Base: SPN & Base: GR \\
\hline$\beta^{5}$ & 0.01 & -0.02 & -0.19 & -0.18 \\
\hline Half-life of Shock (in years) & - & 34.3 & 3.3 & 3.5 \\
\hline $\mathrm{FR}^{6}$ & - & - & 0.02 & 0.00 \\
\hline $\mathrm{GR}^{\mathrm{b}}$ & - & - & 0.09 & - \\
\hline $\mathrm{UK}^{\mathrm{b}}$ & - & - & 0.10 & 0.00 \\
\hline $\mathrm{SPN}^{\mathrm{b}}$ & - & - & - & -0.09 \\
\hline $\mathrm{ITY}^{\mathrm{b}}$ & - & - & 0.07 & -0.07 \\
\hline Lags of $\Delta \mathrm{P}_{\mathrm{i}, \mathrm{k}, \mathrm{t}}$ & $\operatorname{Yes}(1)^{7}$ & $\operatorname{Yes}(1)^{\mathrm{c}}$ & $\mathrm{Yes}^{8}$ & $\mathrm{Yes}^{\mathrm{d}}$ \\
\hline t-star & 8.80 & -19.89 & -8.92 & -8.16 \\
\hline $\mathrm{P}>\mathrm{t}$ & 1.000 & 0.000 & 0.000 & 0.000 \\
\hline Molecule/Country Fixed Effects & No & No & Yes & Yes \\
\hline Time Trend & No & No & No & No \\
\hline $\mathrm{N}$ & 2,940 & 3,210 & 2,940 & 3,210 \\
\hline
\end{tabular}

\footnotetext{
${ }_{6}^{5} \beta$ coefficients are estimated by the Levin et al. (1992) panel unit root test module in Stata ${ }^{\mathrm{TM}} 9.2$ (levinlin).

${ }^{6}$ Country fixed effects are estimated for each molecule/country by the Augmented Dickey Fuller unit root test module in Stata ${ }^{\mathrm{TM}}$ 9.2 (dfuller) and then averaged for each country.

${ }^{7}$ The average number of lags for each molecule/country is 1 .

${ }^{8}$ The number of lags is determined by using the Campbell and Perron top-down approach.
} 
Slightly smaller molecule/country price differentials emerge, which are higher than Spain by $11 \%$ for France, $47 \%$ for Germany, 53\% for the UK and 37\% for Italy, and lower than Germany by 50\% for Spain, 39\% for Italy, $0 \%$ for France and the United Kingdom. In addition, all specifications are also estimated using model 3, which includes a time trend. The expected results, that the deviations from the long term differences are eliminated in approximately a year, are obtained. This is shorter than without the time trend in model 2, but the long term price differences remain about the same.

In addition, the same hypotheses are tested for unadjusted prices. In this case, model 3, which includes a time trend, is also reported in the tables for comparison purposes. Table 3 reports the results for the three models. The results remain robust for the absolute version of the law of one price. In model 2, the estimated rates of convergence are very similar to the adjusted price estimates, but molecule/country fixed effects show very high price differences which are expected due to not accounting for quality adjustments.

Table 3

Results for Price Convergence Estimations for All Molecules (Unadjusted)

\begin{tabular}{|c|c|c|c|c|c|c|c|c|c|}
\hline & \multicolumn{3}{|c|}{ Model 1} & \multicolumn{3}{|c|}{ Model 2} & \multicolumn{3}{|c|}{ Model 3} \\
\hline $\begin{array}{l}\text { Dependent } \\
\text { Variable: } \Delta \mathrm{P}_{\mathrm{i}, \mathrm{k}, \mathrm{t}}\end{array}$ & $\begin{array}{l}\text { Base: } \\
\text { SPN }\end{array}$ & $\begin{array}{l}\text { Base: } \\
\text { GR }\end{array}$ & $\begin{array}{c}\text { No } \\
\text { Base }\end{array}$ & $\begin{array}{l}\text { Base: } \\
\text { SPN }\end{array}$ & $\begin{array}{l}\text { Base: } \\
\text { GR }\end{array}$ & $\begin{array}{l}\text { No } \\
\text { Base }\end{array}$ & $\begin{array}{l}\text { Base: } \\
\text { SPN }\end{array}$ & $\begin{array}{l}\text { Base: } \\
\text { GR }\end{array}$ & $\begin{array}{c}\text { No } \\
\text { Base }\end{array}$ \\
\hline$\beta^{\mathrm{a}}$ & -0.00 & -0.01 & 0.00 & -0.33 & -0.14 & -0.30 & -0.77 & -0.68 & -0.65 \\
\hline $\mathrm{FR}^{\mathrm{b}}$ & - & - & - & 0.16 & -0.02 & -0.66 & 0.16 & -0.02 & -0.90 \\
\hline $\mathrm{GR}^{\mathrm{b}}$ & - & - & - & 0.02 & - & -0.32 & 0.02 & - & -0.44 \\
\hline $\mathrm{UK}^{\mathrm{b}}$ & - & - & - & -0.17 & 0.02 & -0.25 & -0.17 & -0.17 & -0.81 \\
\hline $\mathrm{SPN}^{\mathrm{b}}$ & - & - & - & - & -0.19 & -1.08 & - & -0.79 & -1.50 \\
\hline ITY $^{b}$ & - & - & - & 0.06 & -0.00 & -0.35 & 0.06 & -0.30 & -0.94 \\
\hline Lags of $\Delta P_{i, k, t}$ & Yes $(1)^{\mathrm{c}}$ & Yes(1) & Yes(1) & Yes(1) & Yes(1) & Yes(1) & Yes(1) & Yes(1) & Yes(1) \\
\hline $\begin{array}{l}\mathrm{t}-\mathrm{star} \\
\mathrm{p}>\mathrm{t}\end{array}$ & $\begin{array}{c}-14.19 \\
0.000\end{array}$ & $\begin{array}{l}-8.52 \\
0.000\end{array}$ & $\begin{array}{c}0.18 \\
0.575\end{array}$ & $\begin{array}{c}-30.00 \\
0.000\end{array}$ & $\begin{array}{c}-15.82 \\
0.000\end{array}$ & $\begin{array}{c}-30.78 \\
0.000\end{array}$ & $\begin{array}{c}-94.37 \\
0.000\end{array}$ & $\begin{array}{c}-27.88 \\
0.000\end{array}$ & $\begin{array}{r}-41.37 \\
0.000\end{array}$ \\
\hline $\begin{array}{l}\text { Molecule/Country Fixed } \\
\text { Effects }\end{array}$ & No & No & No & Yes & Yes & Yes & Yes & Yes & Yes \\
\hline Time Dummies & No & No & No & No & No & No & Yes & Yes & Yes \\
\hline $\mathrm{N}$ & 2940 & 3210 & 3790 & 2940 & 3210 & 3790 & 2940 & 3210 & 3790 \\
\hline
\end{tabular}

\section{CONCLUSION/DISCUSSION}

Controlling for variation in quality and market characteristics across countries, both the absolute and relative versions of the law of one price are tested by employing panel data unit root tests. Price convergence is expected in integrated markets like the European Union, but factors like transportation costs, tax differences and regulatory regimes that vary across countries, might produce fixed country-specific price differences. The relative version of the law of one price states that these price gaps tend to return to some long-run level over time, even if this level is not zero. Despite the fact that the data in this analysis control for observable quality and market characteristics, systematic price differences across countries could persist because of the nature of the pharmaceutical market and differences across countries with regard to demographics, culture and medicine consumption attitudes.

For the absolute version, the half life of a shock is 34 years, indicating very slow convergence. The main interest in this study is not the absolute version of the law of price because it is expected that cross country drug price differences cannot be completely eliminated. Results provide evidence in support of the relative version of the law of one price, which is a narrower definition of price convergence and is the key interest of the study. For the relative version, half lives are between 3 and 5 years. The estimated rates of convergence in the EU pharmaceutical

\footnotetext{
${ }^{\mathrm{a}} \beta$ coefficients are estimated by Levin et al. (2002) panel unit root test module in Stata ${ }^{\mathrm{TM}} 9.2$ (levinlin).

${ }^{\mathrm{b}}$ Country fixed effects are estimated for each molecule/country by Augmented Dickey Fuller regressions (dfuller) in Stata ${ }^{\mathrm{TM}} 9.2$ and then averaged for each country.

${ }^{\mathrm{c}}$ The average number of lags for each molecule/country is 1 .
} 
industry are comparatively slower than the rates for analogous studies of different European industries, e.g. half lives of 1.3-1.6 years in the automobile industry. This could be explained by the different health care systems, pricing and reimbursement regulations by the national governments across countries.

Long term price differentials imputed from the estimated molecule/country fixed effects show price differences across markets between $0 \%$ and $40 \%$ for countries other than the UK, providing evidence of market segmentation. Possible sources of the larger long term price differences between the UK and other countries include the fact that the UK is not a member of the "euro zone", transportation costs (e.g. the UK is not contiguous like the other nations) and other different policies by the UK government. According to Kotzian (2004), the reason for these price differences could be the political arena in the EU: some governments grant high prices for newly introduced products to encourage therapeutic innovations, others set a very low price due to health care budget concerns.

This preliminary study contributes new results to the existing literature on European integration and pharmaceutical price convergence. The results show that even though the pharmaceutical industry is one of the most heavily regulated markets with divergent methods in the EU and there are no legislative actions by the European Commission for the pharmaceutical industry toward a single market, price differences across countries do converge over time, albeit relatively slowly, conditional on the molecule/country fixed effects. Although price differences still exist, progress toward the single pharmaceutical market is evident. Possible explanation could be: International reference pricing that create spillover of price levels from one country to another, parallel imports across the EU countries and continuous coordination affords by the European Commission.

The unique molecule level data set in this paper includes branded drugs along with generics, licensed, OTCs and parallel imports, and allows controlling for quality and market characteristics. The empirical results not only demonstrate consistent decrease in the prices overall but also provide evidence of relative price convergence in the pharmaceutical industry. As is emphasized by the European Commission there is no reason to exempt pharmaceuticals from the single market ideal.

Finally, this study attempts to be the first preliminary empirical investigation of the drug price convergence in the EU. This research has also several limitations that should be noted. First, the data set analyzed in this study spans only ten years. Several other studies in the literature use periods of similar length, but as with all time series, a longer series would permit a stronger test of the price convergence hypothesis. It would also allow for testing whether molecule/country effects are declining over time and if the speed of convergence has changed over time. Second, since IMS fixed euro standard unit prices are used to flatten exchange rate fluctuations, the role of exchange rate changes must be investigated separately.

\section{ACKNOWLEDGEMENTS}

I gratefully acknowledge financial support for the data set from the Johnson Endowed Professorship Fund at the Johnson School of Business, Hodges University, and the Gaiennie Foundation at the College of Business Administration, University of South Florida. I also appreciate helpful comments from participants in a seminar at the University of South Florida and sessions at the 2007, 2008 and 2010 Southern Economic Association meetings.

\section{AUTHOR INFORMATION}

Aysegul Timur, Ph.D., is a Professor and Chair of Business Administration and Public Administration programs at the Johnson School of Business, Hodges University. Dr. Timur received her doctoral degree in Economics from the University of South Florida, and both her Master's and Bachelor's degrees in Business Administration from the University of Istanbul. Her areas of specialization include business policy and organizational development, quality control, statistics for strategic planning, health (especially pharmaceutical pricing) and international economics. Her work has been published in several distinguished journals and presented in international and national conferences. E-mail: atimur@hodges.edu 


\section{REFERENCES}

1. Allen, C., Gasiorek, M., Smith, A., Flam, H., and Sorensen, P.B. 1998. "The Competition Effects of Single Market in Europe." Economic Policy, 13:27, pp. 439-86.

2. Berndt, E.R. 2000. "Editorial: International Comparison of Pharmaceutical Prices? What Do We Know, and What Does It Mean?" Journal of Health Economics, 19, pp. 283-87.

3. $\quad$ Bornhorst, F. and Baum, C.F. 2001. "Levin-Lin-Chu Panel Unit Root Test." STATA.

4. Camarero, M., Esteve, V., and Tamarit, C. 2000. "Price Convergence of Peripheral European Countries on the Way to the EMU: A Time Series Approach." Empirical Economics, 25, pp. 149-68.

5. $\quad$ Coopers, L.N.V., UCL. 1996. Price Convergence and Price Levels. http://ec.europa.eu/internal_market/studies/stud3.htm.

6. $\quad$ Danzon, P.M. 1999. Price Comparisons for Pharmaceuticals: A Review of U.S. and Cross-National Studies. Washington, D.C.: The AEI Press.

7. Danzon, P.M. and Chao, L.W. 2000. "Cross-National Price Differences for Pharmaceuticals: How Large, and Why?" Journal of Health Economics, 19, pp. 159-95.

8. $\quad$ Danzon, P.M. and Kim, J.D. 1998. "International Price Comparisons for Pharmaceuticals." Pharmacoeconomics, 14:1, pp. 115-28.

9. Dickson, M. and Jacobzone, S. 2003. "Pharmaceutical Use and Expenditure for Cardiovascular Disease and Stroke: A Study of 12 OECD Countries." OECD Health Working Papers, DELSA/ELSA/WD/HEA (2003)1.

10. DRI. 1996. "Subseries V- Impact on Competition and Scale Effects: Price Competition and Price Convergence." The Single Market Review Series.

11. Ellison, S.F., Cockburn, I., Griliches, Z., and Hausman, J. 1997. "Characteristics of Demand for Pharmaceutical Products: An Examination of Four Cephalosporins." The RAND Journal of Economics, 28:3, pp. 426-46.

12. European Commission. 2004. European Economy: Convergence Report. Special Report No: 2 DirectorateGeneral for Economic and Financial Affairs.

13. Fan, C.S. and Wei, X. 2006. "Price Index Convergence in China." Lingnan University, Department of Economics.

14. Gaulier, G. and Haller, S. 2000. "The Convergence of Automobile Prices in the European Union: An Empirical Analysis for the Period 1993-1999." CEPII, Working Paper, n-00:14, pp. 1-25.

15. Gil-Pareja, S. and Sosvilla-Rivero, S. 2004. "Export Market Integration in the European Union." Journal of Applied Economics, VII:2, pp. 271-301.

16. Goldberg, P.K. and Verboven, F. 2001. "The Evolution of price Dispersion in the European Car Market." Review of Economic Studies:68, pp. 811-48.

17. Goldberg, P.K. and Verboven, F. 2004. "Cross-Country Price Dispersion in the Euro Era: A Case Study of the European Car Market." Economic Policy, pp. 483-521.

18. Goldberg, P.K. and Verboven, F. 2005. "Market Integration and Convergence to the Law of One Price: Evidence from the European Car Market." Journal of International Economics, 65, pp. 49-73.

19. Hellerstein, J. 1998. "The Importance of the Physician in the Generic versus Trade-Name Prescription Decision." The RAND Journal of Economics, 29:1, pp. 108-36.

20. IMS. 2002. "IMS Midas Customized Insights: Data Elements, Measures and Statistics." @ IMS Health Incorporated or Its Affiliates.

21. IMS. 2005a. "Guide to Pack Prices on IMS Midas Quantum."

22. IMS. 2005b. IMS Midas Quantum - Data Elements, Measures and Statistics.

23. Kerem, K., Puss, T., and Viies, M. 2005. "Convergence of Health Care Expenditure in EU." The Global Economic and Research Conference, Istanbul.

24. Kotzian, P. 2004. "Pharmaceutical R\&D Setting of Incomplete European Integration." International Journal of the Economics of Business, 11:2, pp. 177-95.

25. Levin, A. and Lin, C.F. 1992. "Unit Root Tests in Panel Data: Asymptotic and Finite-Sample Properties." University of California, San Diego, Department of Economics, Discussion Paper 92-23.

26. Levin, A. and Lin, C.F. 1993. "Unit Root Tests in Panel Data: New Results." University of California, San Diego, Department of Economics: Discussion Paper 93-56. 
27. Levin, A., Lin, C.F., and Chu, C.-S.J. 2002. "Unit Root Tests in Panel Data: Asymptotic and Finite-Sample Properties." Journal of Econometrics, 108:2002, pp. 1-24.

28. Maddala, G.S. 1999. "On the Use of Panel Data Methods with Cross-Country Data." Annales D'Economie Et De Statistique, 55-56.

29. Maddala, G.S. and Wu, S. 1999. "A Comparative Study of Unit Root Tests with Panel Data and a New Simple Test." Oxford Bulletin of Economics and Statistics, Special Issue.

30. OECD, H.D. 2003. "A Comparative Analysis of 30 Countries."

31. Pammolli, F., Riccaboni, M., and Magazzini, L. 2004. European Competitiveness in Pharmaceuticals.

32. Ratfai, A. 2006. "How Fast Is Convergence to the Law of One Price? Very." Economics Bulletin, 6:10, pp. $1-12$.

33. Rogers, J.H. 2001. "Price Level Convergence, Relative Prices and Inflation in Europe." International Finance Discussion Papers \#699, Board of Governors of the Federal Reserve System.

34. Rogers, J.H., Hufbauer, G.C., and Wada, E. 2001. "Price level Convergence and Inflation in Europe." Working Paper 01-1, Institute for International Economics.

35. Scherer, F.M. 1993. "Pricing, Profits and Technological Progress in the Pharmaceutical Industry." The Journal of Economic Perspectives, 7:3, pp. 97-115.

36. Scherer, F.M. 2000. "The Pharmaceutical Industry." Handbook of Health Economics, 1.

37. Sosvilla-Rivero, S. and Gil-Pareja, S. 2004. "Price Convergence in the European Union." Applied Economics Letters: 11, pp. 39-47.

38. Timur, A., Picone, G., and DeSimone, J. 2010. "Has the European Union Achieved a Single Pharmaceutical Market?" National Bureau of Economic Research (NBER) Working Paper 16261: http://www.nber.org/papers/w16261.

39. Verboven, F. 1996. "International Price Discrimination in the European Car Market." RAND Journal of Economics, 27:2, pp. 240-68. 


\section{NOTES}

